\title{
Doğal ve Tarihi/Arkeolojik Değerlere Sahip Kentsel Kıyı Yerleşimlerinin Planlama Sorunu: Foça Örneği
}

\author{
Tanyel Özelçi Eceral* \\ Afra Taciroğlu**
}

\begin{abstract}
Özet
Kıyı alanlarında yer seçen doğal tarihi/arkeolojik değerlere sahip kentsel kıyı yerleşmeleri kültürel ve doğal değerleri ile dünya ve insanlığın ortak mirasıdır. Nüfusun giderek daha yüksek oranlarda kıyılarda yer seçme eğilimi, taşınmaz kültür ve tabiat varlıklarına sahip yöreleri giderek daha fazla koruma ile gelişme arasında yaşanan bir mücadele alanı haline getirmektedir. Bu çerçevede, doğal ve kültürel varlıkların dünya mirası olarak gelecek nesillere aktarılması salt bir koruma problemi değil, bölgenin sorunlarına ve gelişimine çözüm arayan, yönlendiren bir kent planlama/yönetimi problemi olarak ortaya çıkmaktadır. Bu makalede, birçok doğal ve tarihi/arkeolojik değere sahip İzmir ilinin kıyı yerleşimlerinden Foça ilçesi, doğal ve tarihi/arkeolojik değerleri, ulusal ve uluslararası düzeydeki koruma kararları, farklı ölçekteki planlama süreçleri çerçevesinde ele alınmakta; yörenin süreç içerisinde ve günümüzde yaşadığı planlama sorunları son yıllarda uluslararası kuruluşlarca ve akademik çevrelerce de ele alınan kent yönetimi/planlama ve kentsel koruma alanlarında yaşanan paradigma değişimleri bağlamında tartışılmaktadır.
\end{abstract}

Anahtar sözcükler: Kentsel doğal ve tarihi/arkeolojik değerler, koruma, planlama, Foça, İzmir

\section{Abstract \\ Planning Problems of Coastal Urban Settlements with Natural Historical/ Ar- cheological Assets: The Case of Foça}

Urban settlements located in coastal areas with natural and historical/archeological assets are the common heritage of the world and humankind. The increasing tendency of the population to settle in coastal areas make these type of settlements areas of struggle between development and conservation. In this respect, transferring cultural and natural assets to future generations is not solely a conservation problem but a problem of planning/management, which seek to guide and also find solutions to development problems. Within this framework, Foça, one of the historical, natural and coastal districts of Izmir, is examined through its natural and historical/ archeological characteristics, the conservation decisions and planning processes in different scales in this article. Planning problems of the settlement is dicussed especially in the context of paradigm shift in conservation and planning approaches of academic and international institutions' studies during the recent years.

Keywords: Urban natural and historical/archaeological assets, conservation, planning, Foça, Izmir

* Gazi Üniversitesi, Şehir ve Bölge Planlama Bölümü

** Gazi Üniversitesi, Şehir ve Bölge Planlama Bölümü 


\section{Giriş}

Günümüzde kentler, küreselleşmenin de etkisiyle çeşitliliğin, uzmanlaşmanın, etkileşimin ve karmaşıklığın arttığı bir sistem içinde kendilerini sürekli yeniliklere uyumlandırarak gelişmektedir. Bu dinamizm bir yandan küresel kentler, kent bölgeler, megapoller gibi büyük ölçekli yerleşimleri homojenleşme sürecinin etkisine alır. Diğer yandan daha küçük ölçekli yerleşimlerde özelleşen ve uzmanlaşan farklılaşma sürecinin etkisinde tarihi, kültürel, doğal değerler ile turistik merkezler gibi odaklar ile üretim ve teknoloji odakları gelişmektedir.

Kıyı alanlarında yer seçen doğal tarihi/arkeolojik değerlere sahip kentsel kıyı yerleşmeleri kültürel ve doğal değerleri ile nüfusun giderek daha fazla yer seçme eğiliminde olduğu yerleşimler olmaktadır. Bu durum taşınmaz kültür ve tabiat varlıklarına sahip bu yöreleri giderek daha fazla koruma ile gelişme arasında yaşanan bir mücadele alanı haline getirmektedir. Bu çerçevede, doğal ve kültürel varlıkların dünya mirası olarak gelecek nesillere aktarılması salt bir koruma problemi olmaktan daha çok, bölgenin gelişimine yönelik problemler ile birlikte kentin planlama ve yönetimi problemi olarak ortaya çıkmaktadır.

Uluslararası kuruluşlar bu zorluklara karşı süreç içerisinde bazı standart araçlar geliştirmiş ve birtakım hassas kavramlar ve uygulamalı araçlar önermiştir. UNESCO'nun 1972 tarihli Dünya Kültürel ve Doğal Mirasın Korunması Sözleşmesi ve 2011 tarihli Tarihi Kentsel Peyzaja İliş̧kin Tavsiye Kararı, kentsel yerleşimlerde kültürel ve doğal değerlerin temel ilkeler olarak kabul edildiği holistik yaklaşımlar geliştirmek için kentlerin sosyal, ekonomik ve mekânsal bileşenlerini bütünleştiren çağdaş toplumlarda doğal ve kültürel mirasın dinamik rolü ve işlevine ve bunun planlama politikalarına dahil edilmesine odaklanmıştır.

Kentsel yerleşmelerin tabiatında var olan değişim süreci günümüzde kentlerin yönetiminde tüm problemlerin ve zorlukların kaynağı olarak ortaya çıkmaktadır. ${ }^{1}$ Tarihsel, doğal, kentsel peyzajlar söz konusu olduğunda bu değişim ve dönüşümlerin nereye kadar gidebileceği konusunda bir uzlaşmaya var1lamamaktadır. Ekim 2016'da gerçekleştirilen Habitat III Küresel Zirvesi'nde, 21. yüzyılda yeni kentsel gündem çerçevesinde, kentsel yönetim için "değişimin kabul edilebilir sınırları" analizine odaklanan stratejiler geliştirmek üzere öneriler tartışılmıştır. Bütünleştirici bir perspektiften, tarihi kentlerde var olan değerlerin ve özelliklerin korunmasını ve gelecek kuşaklara aktarılmasını sağlayacak, koruma, yenilik ve gelişmenin planlama sistemi çerçevesinde uzlaştırılması yolları aranmaktadır. Bu bağlamda son yıllarda klasik “kentsel koruma" paradigmasının dönüşümüne tanıklık ediliyor.

Son dönemde, akademik ve uluslararası tartışmalarda, örneğin tarihi kentlerin eski bölümlerini kentsel alanın diğer bölgelerinden ayrı mekânsal birimler olarak düşünmenin problemli bir yaklaşım olduğu, bu tür özellikli bölgelerin kentsel dinamiklerin akışları içerisinde yer aldığının kabul edilmesi gerektiği görüşü kabul görmektedir. ${ }^{2}$ Bu çerçevede, kültürel ve doğal mirasın korunması ve yönetimi ile mekânsal planlama ve gelişme stratejilerinin ve

1 Arturo Azpeitia Santander ve Agustín Azkarate Garai-Olaun, "Urban Planning and Sustainable Development in the 21st Century, Conceptual and Management Issues", IOP Conference Series: Earth and Environmental Science 44, no. 3 (2016): 032005, https://doi. org/10.1088/1755-1315/44/3/032005.

2 Santander ve Garai-Olaun, “Urban Planning and Sustainable Development in the 21st Century". 
araçlarının entegre edildiği yeni kavramlar ve profesyonel uygulamalar ortaya çıkmaktadır. Kentsel koruma artık kentsel sistem içerisinde kültürel değerlerin arttırılması ve değişimin yönetilmesini amaçlayan dinamik bir süreç olarak ele alınmaktadır.

Bu tartışmalar çerçevesinde, bu makalede, İzmir kent bölgesinde yer alan doğal ve tarihi değerlere sahip Foça kıyı yerleşimi ele alınmaktadır. Foça'da bulunan arkeolojik ve doğal sitler ile geniş askeri bölgeler, uzun yıllardır yörenin nüfus yapısı, mekânsal, ekonomik ve özellikle de turizm gelişimi çerçevesinde tartışmalı gündemler oluşturmaktadır. Türkiye'de bir yandan 2863 sayılı Kültür ve Tabiat Varlıklarını Koruma Yasası ve yönetmelikleri çerçevesinde uygulanan koruma alanları ve koruma amaçlı imar planları yürürlükte iken diğer yandan da çok sayıda plan türünün yer aldığı üst ölçekli planlar ile nazım ve uygulama imar planlarının yönlendirdiği planlama sisteminin varlığı, bu tür özellikli bölgelerde yetki karmaşasına yol açarak uygulamada sorunları çözmek yerine daha da karmaşık hale gelmesine neden olmaktadır.

Makalenin bir sonraki bölümünde Foça'nın demografik, sosyo-ekonomik, tarihi/arkeolojik, doğal özellikleri ortaya konmaktadır. Daha sonra Foça'ya ilişkin alınmış koruma kararları sunulmaktadır. Türkiye'nin planlama sistemi içerisinde yer alan çok sayıdaki plan türü içerisinde üst ölçekli planlardan imar planlarına kadar olan sistem içerisinde Foça için alınan kararlar değerlendirildikten sonra, Foça'nın planlama alanında karşı karşıya olduğu sorunlar tartışılmakta; sonuç olarak da son dönem akademik ve uluslararası kuruluşlarda yer alan koruma ve planlama tartışmaları çerçevesinde, göz önünde bulundurulması gereken hususlar ele alınmaktadır.

\section{Doğal Tarihi/Arkeolojik Değerlere Sahip Kıyı Yerleşimi Foça}

Foça, İzmir ilinin 30 ilçesinden biridir. Doğusunda Menemen ilçesi, batısında Ege Denizi, kuzeyinde Aliağa ilçesi, güneyinde de İzmir Körfezi yer alır. İzmir'in üç büyük havzasından biri olan Gediz Havzası'nda yer almaktadır. İlçenin yüzölçümü 228 kilometre karedir. Toplam yüzölçümünün, kabaca, \%51'i orman, \%'u mera, $\% 5^{\prime}$ i yerleşim yeri, $\% 10^{\prime}$ u diğer alanlar ve $\% 25^{\prime}$ i de tarım arazisinden oluşmaktadır.

Foça ve yakın çevresinin 1945 yılında askeri yasak bölge ilan edilmesiyle kent hızla göç vermeye başlamıştır. Nüfus verilerine göre, Foça'da 1945 y1lında 3.484 olan merkez nüfusu, 1955 yılına kadar yarı yarıya azalarak 1.738'e kadar düşmüştür. Bu dönemde ilçenin toplam nüfusu ise 10.000 civarındadır. 1960'1 yıllardan sonra askeri yapılanmanın değişimiyle nüfus tekrar artmaya başlamış ve yeni yapı inşası hız kazanmıştır. 2000 yılına gelindiğinde Foça merkez nüfusu 14.064 iken ilçenin toplam nüfusu 36.107'ye ulaşmıştır. Adrese Dayalı Nüfus Kayıt Sistemi verilerine göre Foça ilçesinin 2016 yılı toplam nüfusu 28.591 kişidir. Ancak yaz aylarında yazlıkçıların da gelmesi ile nüfusun 70.000'leri aştığ 1 tahmin edilmektedir.

Günümüzde Foça'nın yaklaşık 800 hektarı askeri alanlardan oluşmaktadır. Askeri alanların yaklaşık 600 hektarı ilçenin güneybatısında yer almaktadır ve bu alanlar bozulmadan-parçalanmadan doğayı koruma işlevi görmektedir. Ayrıca Foça yerleşimini sınırlandıran askeri alanlar, yerleşimlerin kentsel dokuyu etkileyecek şekilde yükselmesini engellemektedir.

2014-2023 İzmir Bölge Planı çalışmaları çerçevesinde gerçekleştirilmiş olan Fonksiyonel Bölgeleme ve Alt Bölgeleme analizi çalışması kapsamında 2000 yılı verilerine göre Foça'daki sektörel işgücü dağılımlarında ilk üç sırayı toplum 
hizmetleri, sosyal ve kişisel hizmetler; ziraat, avcılık, ormancılık ve balıkçılık ile toptan ve perakende ticaret, lokanta ve oteller sektörlerinin aldığı görülmektedir. ${ }^{3}$ Foça'da büyük bir balıkçılık potansiyeli olmakla birlikte, 1990 yılında Foça'nın Özel Çevre Koruma Bölgesi ilan edilmesiyle yöre, geleneksel yöntemlerle yapılan küçük kıyı balıkçılıkları hariç "her türlü balıkçılığa kapatılmıştır". ${ }^{4}$ Foça'da sanayi sektörünün ise gelişmediği görülmektedir. Mevcut sanayi sadece tarıma dayalı küçük işletmelerden oluşmaktadır. Foça'nın turizm potansiyeline bakıldığında ilçenin doğal güzellikleriyle ve altı adet mavi bayraklı plajıyla yaz mevsiminde birçok turist çektiği görülmektedir. Deniz ve kıyı alanları, ulusal ve uluslararası öneme sahip koruma alanlarıdır.

\section{Foça'nın Tarihçesi, Tarihi/Arkeolojik ve Kültürel Değerleri}

Akdeniz'in Atlas Okyanusu ve Hint Okyanusu'na açılan konumu nedeniyle tarihi boyunca kıyı yerleşimlerinde ticari faaliyetler yoğunlaşmıştır. ${ }^{5}$ Ticari faaliyetlerin yoğunlaşması, geçmişten günümüze, bu yerleşimlerde barınan uygarlıkları çeşitlendirmiş ve böylece tarihi/kültürel katmanlar oluşmuştur. Birçok doğal ve tarihi/arkeolojik değere sahip İzmir ilinin kıyı yerleşimlerinden Foça ilçesi de Akdeniz'in önemli bir kıyı yerleşimi olmasıyla birçok uygarlığa ev sahipliği yapmış ve antik çağın 12 İyon yerleşiminden biri olmuştur.

Antik yazarlara göre, Atinalı önderlerin idaresinde gelen Phokaialılar, Kymelilerin izin verdiği yerde ilk yerleşmelerini kurmuşlardır. ${ }^{6}$ Günümüzde Foça'da İyon, Pers, Roma, Bizans ve Osmanlı medeniyetlerden kalmış birçok yapı bulunmaktadır. Özellikle Pers işgaline ilişkin bölgede bulunan nadir kalıntıların önemli bir kısmı burada yer almaktadır.?

Ceneviz ve Osmanlılardan kalma tarihi yapılarla, Ege mimarisine özgü sivil mimari yapılarının yer aldığı kentte arkeolojik değerlere ulaşabilmek için kazılar yapılmıştır. Yapılan arkeolojik kazılar üç dönemden oluşmaktadır. ${ }^{8}$ İlk dönemde Foça'da arkeolojik kazıları başlatan Felix Sartiaux 1913, 1914 ve 1920 yıllarında sondajlar yapmıştır. Sartiaux'nun tüm bu sondaj kazıları savaş yıllarına rastladığından bu çalışmalar uzun süreli olmamıştır. 1920'lerden sonra Foça'da uzun süre bilimsel nitelikli kazılar yapılmamıştır. ${ }^{9}$

İkinci dönem kazılar 1950’lerde Ekrem Akurgal öncülüğünde gerçekleştirilmiştir. Foça'nın Aiol bölgesi içinde bir İyon yerleşmesi olması, MÖ 7. yüzyılın sonu ile 6. yüzyılın ilk yarısında Helen dünyasında önemli bir yere sahip olması ve Batı Akdeniz'de koloniler kurması yönünden incelenmesi gereken

3 İZKA, “2014-2023 İzmir Bölge Planı İlçe Toplantıları Foça İlçe Raporu, Mayıs 2013”, erişim tarihi 7 Kasım 2016, http://www.izmiriplanliyorum.org/static/upload/file/2014-2023_ilce_ ozet_raporu_-_foca.pdf.

4 Hikmet Hoşsucu vd. "Balıkçılık Sektörünün İzmir İli İçindeki İşleyişi ve Güncel Sorunları", E.Ü. Su Ürünleri Dergisi 18, no. 3-4 (2001): 437-444.

5 Zeki Arıkan, "Henri Pirenne ve Fernand Braudel'e Göre Akdeniz", Akdeniz Tarihi, Kültürü ve Siyaseti "Çoğulluğu ve Farklılı̆̆ İçeren Bir Birlik Özlemi" Sempozyum Bildirileri içinde, der. Alp Yücel Kaya, Ayşegül Sabuktay, Dilek Akyalçın Kaya, Ertekin Akpınar (İzmir: İzmir Akdeniz Akademisi, 2016), 39-48.

6 Ömer Özyiğit, “Phokaia'da Akurgal'ın Kazıları Işı̆̆ında Son Dönem Çalışmaları”, Anadolu / Anatolia 25 (2003): 97-107.

7 İKA ve Dokuz Eylül Üniversitesi Mimarlık Fakültesi, İzmir 2012 Kültür Ekonomisi ve Kültür Altyapısı Envanteri ve İzmir Kültür Ekonomisi Gelişme Stratejisi (İzmir: İZKA, 2013).

8 Ömer Özyiğit, "Recent Discoveries At Phocaea”, Empúries 56 (2009-2011): 25-40.

9 Özyiğit, "Phokaia'da Akurgal'ın Kazıları Işığında Son Dönem Çalışmaları". 
bir merkez olması, kazıların burada yeniden başlamasına neden olmuştur. ${ }^{10}$ Daha sonra, 1970'lerde, yapılan kazılar genellikle yarımada üzerinde gerçekleştirilmiş ve kazılarda arkaik kent yerleşiminin varlığı anlaşılmıştır. ${ }^{11}$

Son dönem kazıları, yani üçüncü dönem kazıları, bir tesadüf sonucu başlamıştır. 1989 yılında Foça'nın kuzey bölümünde, arsa sahiplerinin isteği üzerine sit alanlarının derecelerini düşürmek amacıyla, Kültür Bakanlığı'nın izniyle, arkeolojik kalıntıların var olup olmadığını saptamak üzere suni bir tepe olan Roma Dönemi seramik çöplüğünde İzmir Müzesi sondaj kazılarına başlamıştır. Kentin ortasında kalan I. Derece Arkeolojik Sit Alanı olan bu tepede yapılan kazılar sonucunda çıkan buluntular ${ }^{12}$ ile üçüncü dönem kazıları Ömer Özyiğit başkanlığında başlamıştır. Bu kazılarda MÖ 7. ve 6. yüzyıl yerleşimlerinin üzerinde Klasik, Helenistik, Roma ve Bizans dönemlerine ait katların üst üste olduğu, böylelikle kentin asıl yerleşiminin anakarada bulunduğu, arkaik dönemde sınırlarının oldukça büyük olduğu, yarımadada ise daha önemli yapıların var olduğu, özellikle tapınakların bulunduğu sonucuna ulaşılmıştır. ${ }^{13}$ Ayrıca bu alanın hemen kuzeyinde Roma Dönemi seramik çöplüğünün altında ve biraz daha kuzeydeki bir parselde yapılan kazılarda ortaya çıkarılan MÖ 7. yüzyıla ait bir megaron yapısı, Arkaik dönemde yerleşimin oldukça büyük olduğunu ortaya koymuştur. ${ }^{14}$ Son dönem kazılarında arkaik dönem kentinin yeri belirlendikten sonra arkaik dönemin kent kapısı ve kent Surları, " Herodotos'un sözünü ettiği o ünlü surlar", ${ }^{15}$ bulunmuştur. Uzunluğu $5 \mathrm{~km}$ 'den çok daha fazla olan bu surlar "Phokaia'nın MÖ 6. yüzyıl başlarında dünyanın en önemli ve en büyük kentlerinden biri olduğu gerçeğini"16 ortaya koymuştur. Bunlar dışında son dönem kazılarında arkaik yerleşimin nekropolisine, Pers Mezar Anıtı́na (MÖ 4. yüzyıl), Kybele Kutsal Alanı'na, Anadolu'nun en eski Tiyatrosu'na (MÖ 340-330) ve Athena Tapınağı'na (MÖ 6. yüzyıl) ulaşılmıştır.

Foça'da bulunan diğer tarihi/arkeolojik değerler, "Şeytan Hamamları (MÖ 5. yüzyıl), Dış Kale -Ceneviz Kalesi (1678), Beşkapılar (Osmanlı Dönemi Kayıkhanesi), Roma Dönemi Mozaikleri (5. yüzyıl Villa Yapısı) ve Fatih Cami'dir (1455)."17 İzmir 2012 Kültür Ekonomisi ve Kültür Altyapısı Envanteri'ne göre Foça'da bir anıt/abide, dört dinsel yapı, altı doğal varlık, yedi endüstriyel/ticari yapı, bir askeri/idari/sağlık yapısı, 270 konut/konut ve dükkân, 16 taşınmaz, iki köprü/su kemeri/kuyu, üç hamam/1lıca/sarnıç vb., üç çeşme sebil, üç mezar/mezarlık ve iki duvar vb. kalıntılar olmak üzere toplam 318 adet taşınmaz kültür varlığı bulunmaktadır. Foça'da 16 arkeolojik, 18 doğal ve beş kentsel olmak üzere toplam 50 adet sit alanı vardır.

Yapılan çalışmalar sonucunda elde edilen tarihi/arkeolojik bulgular ve kültürel değerler Foça'nın geçmişinin günümüze yansıması olarak karşımıza çıkmaktadır. Foça'nın birçok uygarlığa ev sahipliği yapan tarihi/kültürel katmanlardan oluşması, arkaik dönemde Akdeniz'in en büyük yerleşimlerinden

10 Özyiğit, "Phokaia'da Akurgal'ın Kazıları Işığında Son Dönem Çalışmaları”.

11 Özyiğit, "Phokaia'da Akurgal'ın Kazıları Işığında Son Dönem Çalışmaları".

12 Özyiğit, "Phokaia'da Akurgal'ın Kazıları Işığında Son Dönem Çalışmaları".

13 Özyiğit, "Phokaia'da Akurgal'ın Kazıları Işığında Son Dönem Çalışmaları".

14 Özyiğit, "Phokaia'da Akurgal'ın Kazıları Işığında Son Dönem Çalışmaları".

15 Özyiğit, "Phokaia'da Akurgal'ın Kazıları Işığında Son Dönem Çalışmaları".

16 Özyiğit, "Phokaia'da Akurgal'ın Kazıları Işığında Son Dönem Çalışmaları".

17 İKA, “2014-2023 İzmir Bölge Planı İlçe Toplantıları Foça İlçe Raporu, Mayıs 2013”. 
biri olması, kilometrelerce uzanan kent surlarını bünyesinde barındırması, Anadolu'nun en eski tiyatrosuna sahip olması, Athena Tapınağı gibi tarihin en eski ve görkemli yapılarına ev sahipliği yapması ve birçok taşınmaz kültür varlığının bulunması, ilçede bulunan tarihi/arkeolojik ve kültürel değerlerin sürdürülebilirlik kapsamında korunmasını daha da önemli kılmaktadır.

\section{Foça'nın Doğal Değerleri}

Foça, doğal güzellikleriyle de ön plana çıkan bir ilçedir. İlçenin doğal liman yapısı ve adaları turizm potansiyelini arttırmaktadır. Bunun yanı sıra, Foça'ya adını veren, nesli tehlike altında olan ve dünyada sadece 400 tane kaldığı düşünülen Akdeniz foklarının yaklaşık dörtte biri Foça kıyılarında yaşamaktadır. Bundaki en büyük etken dik kayalık bir yapıya sahip kıyıların Akdeniz foklarının yaşam alanı için uygun bir ortam sunmadır. Orak Adası'nın batı kısmını oluşturan Siren Kayalıkları, barındırdığı mağaralarla en önemli fok yaşam alanlarını oluşturmaktadır. Bu alanlar 1990 yılında Özel Çevre Koruma Bölgesi ilan edilmiş, 1995 yılından beri geleneksel yöntemlerle avlanan küçük kıyı balıkçıları hariç her türlü kullanıma kapatılmıştır. ${ }^{18}$ Akdeniz fokları dışında dünyada sadece Akdeniz'de bulunan ve koruma altında olan deniz çayırları da bu alana koruma statüsü verilmesinde etken olmuştur.

Akdeniz foklarını tehdit eden etkenler "yaşam alanlarının (kıyıların) betonlaşması, yasadışı ve aşırı su ürünleri avcılığı, fokların kasti öldürülmesi, fok mağaralarında rahatsız edilmeleri, deniz ve kıyıların kirlenmesi" ${ }^{\prime 19}$ olarak sıralanabilir. Akdeniz fokları koruma bölgesi dışındaki alanlarda da beslendiğinden kıyı kesimindeki insan faaliyetleri ve yapılaşmalar önem kazanmaktadır.

Foça ilçesi, yöresinde barındırdığı Tepeli Karabatak türü nedeniyle Önemli Kuş Alanları statüsünü de kazanmıştır. Ancak bu kuş türlerine yaşam ortamı sunan Hayırsız Adası, Kartdere Adası ve Kartdere Vadisi Özel Çevre Koruma Bölgesi dışında kalmakta; Foça Özel Çevre Koruma Bölgesi sınırlarının, adaları ve vadiyi içine alacak şekilde Aslan Burnu'na kadar geniş̧letilmesi tartışma konusu olmaktadır.

Yaban hayatı koruma çerçevesinde, Akdeniz foku ve bölgede yaşayan diğer canlılar için hayati önem taşıyan en önemli konu habitatın (yaşam alanlarının) bozulmamasıdır. Bu çerçevede Foça'da sürdürülebilirlik ilkesine dayalı, çevreyi ve doğal değerleri koruyucu planlama yaklaşımlarının önemi ortaya çıkmaktadır.

Foça'nın Doğal ve Tarihi/Arkeolojik Değerlerine İlişkin Koruma Kararlart ve Koruma Alanları

Kültür ve Tabiat Varlıklarını Koruma Yüksek Kurulu'nun 1980 tarihli kararı ile Foça, Birinci Derece Arkeolojik ve Doğal Sit Alanı olarak ilan edilmiştir. Sit sınırları 12.7.1983 tarihli Koruma Kurulu Kararı ile 2863 Sayılı Kültür ve Tabiat Varlıklarını Koruma Kanunu uyarınca yeniden onaylanmış ve alan Birinci Derece Arkeolojik Sit olarak tanımlanmıştır. ${ }^{20}$

18 Salman Özüpekçe, “Turizm Yerleşmelerinde Nüfusun Sosyo-Ekonomik Özelliklerinde Ortaya Çıkan Değişimler ve Eğitim Üzerindeki Etkisi (Foça Örneği)" (Yüksek Lisans Tezi, Dokuz Eylül Üniversitesi, 2008).

19 Cem Orkun Kıraç ve Harun Güçlüsoy, Foça ve Akdeniz Foku: Foça Özel Çevre Koruma Bölgesi'nde Akdeniz Fokunun (Monachus monachus) Korunması ve İzlenmesi (Ankara: T.C. Çevre ve Orman Bakanlığı Özel Çevre Koruma Kurumu Başkanlığı Yayınları, 2008).

20 T.C. Çevre ve Şehircilik Bakanlığı, Foça Özel Çevre Koruma Bölgesi Yönetim Planı Raporu (Ankara: T.C. Çevre ve Şehircilik Bakanlığı Tabiat Varlıklarını Koruma Genel Müdürlüğü, 2011). 
1990 yılında ise sit alanlarında derecelendirme yapılarak korunan-yönetilen alanlar kapsamında Foça ilçe merkezi ve çevresi İzmir I No.'lu Kültür ve Tabiat Varlıklarını Koruma Kurulu'nun 4.1.1990 tarih ve 2560 sayılı kararı ile I. II. ve III. Dereceden Arkeolojik ve Doğal Sit Alanları olarak ilan edilmiştir. ${ }^{21}$

Foça'da doğal değerler uluslararası ölçekte, Foça ilçesi nesli tehlike altında olan Akdeniz Fokları Yaşama ve Üreme Alanı olarak tanımlandığı için, "Akdeniz'in Kirlenmeye Karşı Korunması (Barselona) Sözleşmesi (1981), Akdeniz'in Deniz Çevresinin ve Kıyı Alanlarının Korunması Sözleşmesi (Barselona Sözleşmesine değişiklik getiren sözleşme) (2000), Avrupa Yaban Hayatı ve Yaşam Ortamlarının Korunması (Bern) Sözleşmesi (1984), Akdeniz'de Özel Koruma Alanları ve Biyolojik Çeşitliliğe İlişkin Protokol (2002), Nesli Tehlikede Olan Yabani Hayvan ve Bitki Türlerinin Uluslararası Ticaretine İlişkin Sözleşme CITES (Washington) (1996) ve Biyolojik Çeşitlilik Sözleşmesi (1996)"22 ile korunmaktadır. Ayrıca Foça ilçe sınırları içerisinde de yer alan Gediz Deltası Kuş Cenneti, 1998 yılında Ramsar (Sulak Alan) Sözleşmesi ile koruma alanı statüsü kazanmıştır. Ulusal ölçekte ise Foça ilçesinde yaklaşık 60 çift Tepeli Karabatak türünün olması nedeniyle, Foça adaları 1997 yılında Türkiye'nin Önemli Kuş Alanları (ÖKA) olarak belirlenmiştir. 2004 yılında da ilçede iki çift Tavşancıl üremesinin belirlenmesiyle bu alan Foça yarımadasını ve tüm adaları kapsayacak şekilde genişletilmiştir. Akdeniz foklarını ve fokların yaşam alanları olan kıyı alanlarını yasal olarak korumak için Ocak 1991'de ilgili kurum kuruluşlar ile konusunda ihtisas sahibi STK ve üniversitelerin katılımı ile Ulusal Fok Komitesi ilk çalışmasına başlamış, 'Akdeniz Fokunun Korunması İçin Ulusal Strateji' belgesini benimsemişlerdir." 23

Foça ilçesinde 1. derece arkeolojik, 3. derece arkeolojik, 1. derece doğal, 1. derece doğal ve arkeolojik, 1 . derece doğal ve 3. derece arkeolojik, 2. derece doğal, 3. derece doğal, 3. derece doğal ve arkeolojik, kentsel ve arkeolojik, kentsel ve 3. derece arkeolojik olmak üzere 10 çeşit sit alanı bulunmaktadır (Harita 1).

Kıyı kesiminde ve adalarda yoğunlaşan sit alanlarından 1. derece arkeolojik sit alanı 100 hektar, 3. derece arkeolojik sit alanı 120 hektar, 1. derece doğal sit alanı 1.300 hektar, 1 . derece doğal ve arkeolojik sit alanı 150 hektar, 1. derece doğal ve 3. derece arkeolojik sit alanı 10 hektar, 2. derece doğal sit alanı 300 hektar, 3. derece doğal sit alanı 100 hektar, 3. derece doğal ve arkeolojik sit alanı 10 hektar, kentsel ve arkeolojik sit alanı 60 hektar, kentsel ve 3. derece arkeolojik sit alanı 30 hektarlık alanları kaplamaktadır. Yüzölçümü 22.800 hektar olan Foça'nın yaklaşık 2.180 hektarlık sit alanı bulunmaktadır ve bu değer Foça'nın yaklaşık \%10'unu oluşturmaktadır. Sit alanlarının çok fazla olması ve özellikle de kıyı kesiminde yoğunlaşması, Foça'nın planlamasında geçmişten günümüze büyük bir sorun olarak karşımıza çıkmaktadır. Bu soruna sebep olan en önemli etken ise sit alanlarının yapılaşma koşullarıdır.

21 Erhan Ergürhan, “Foça'da Kıyı Alanı Kullanımı ve Kıyı Kullanımı Bilincinin Değerlendirilmesi" (Yüksek Lisans Tezi, Dokuz Eylül Üniversitesi, 2008).

22 Kıraç ve Güçlüsoy, Foça ve Akdeniz Foku.

23 Kıraç ve Güçlüsoy, Foça ve Akdeniz Foku. 


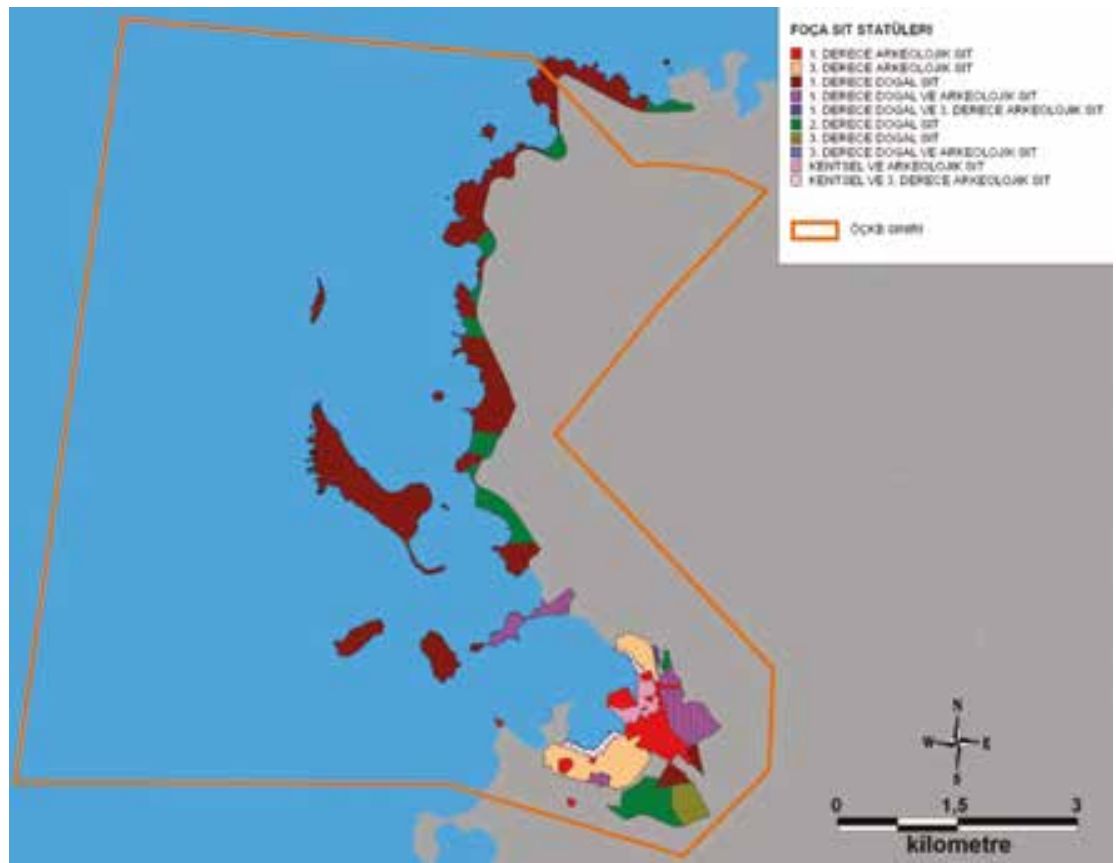

Harita 1. Foça Özel Çevre Koruma Bölgesi Sit Alanları (Kaynak: T.C. Çevre ve Şehircilik Bakanlığı, Foça Özel Çevre Koruma Bölgesi Yönetim Planı Raporu, 6.)

Yapılaşma koşullarında, 1. derece arkeolojik sitlerde kesin yapılaşma ve tarım (elle yapılan tarım hariç) yasağı vardır. Mevcut yapılar kamulaştırılır veya ömürlerini tamamlayana kadar kullanım izni verilebilir. 2. derece arkeolojik sitler yapılaşma yasağı olan alanlardır. Ancak mevcut yapıların temellerini kullanarak yapıların yenilenmesine izin verilir. 3. derece arkeolojik sitler koruma alanları diye isimlendirilirler. 2. derece arkeolojik sitlerde de sera tar1mına izin verilebilir. Makinalı tarım söz konusu değildir. Kültür Bakanlığı'nın izni ve Bakanlığın o yerdeki biriminden belirlenecek bir uzman gözetiminde hafriyat yapılmasına izin verilir. Kazı sırasında bir buluntuya rastlanmaması durumunda yapılaşma devam eder. Aksine bir durum söz konusu olur ise alan 1. derece arkeolojik sit ilan edilir ve bu dereceye ait koşullar geçerli olur. Aynı şekilde bu alanlarda tarım yapılabilir. Bir buluntu halinde yasa gereği ilgili en yakın askeri, idari veya kolluk kuvvetine başvurma zorunluluğu vardır. Yasanın cezai müeyyideleri ağırdır ve tecili yoktur. Bu durumda yine 1. derecede arkeolojik sit koşulları geçerlidir. ${ }^{24}$

Kentsel sitler, taşınmaz kültür varlıklarının bulunduğu kent ve kent parçalarıdır. Kentsel sit alanlarında dokuyu bozmayacak yeni yapılaşmaya izin verilebilir. Bu durumda yapı taban alanı, gabarisi ve mimari özellikleri koruma kararları doğrultusunda uygulanır ve dokunun sürekliliğinin sağlanması esastır. Strüktürel sorunları olan bir yapı yenilenebilir, boş bir parsele yapı yapma hakkı tanınabilir, ancak tüm uygulamalar için belediyeden ve ilgili Kültür Varlıkları Koruma Bölge Kurulu'ndan izin alınması zorunludur.

24 Nevin Gültekin, "Kentsel Korumada Temel Kavramlar", Kentsel Koruma Ders Notları içinde (2015), 3-4. 
Doğal (tabii) sitler, jeolojik devirlere aittir. Ender bulunmaları nedeniyle yer üstünde, yer altında veya su altında olağanüstü özelliklere sahip bulunan korunması gerekli alanlardır. Büyük çoğunlukla geniş toprak parçalarını kapsarlar. Bu itibarla korunmaları en zor ve yapılaşma tehdidi altındaki alanlardır. 1. derecede doğal sitler ender bulunan jeolojik oluşumların veya ender bulunan ağaç gruplarının olduğu yerlerdir. Kesin yapılaşma yasağı vardır. 2. derecede doğal sitlerde sınırlı yapılaşmaya izin verilebilir. Ancak yapılaşmanın bu doğal varlıkları zedelememesinin sağlanması için büyük alanlar üzerinde minimum yapı hakkı verilmesi esastır. Doğal sit alanlarında ağaç kesmemek kaydı ile tarım yapılabilir. ${ }^{25}$

Foça'da tarihi/arkeolojik doğal değerlerin korunmasına ilişkin süreç içerisinde çok sayıda karar alındığı görülmektedir. Bu kararlar bölgede yapılan kazılarda elde edilen bulgular 1şığında değişmekle birlikte, sit alanlarının s1nırlarının daraltılması, genişletilmesi, derecelerinin değiştirilmesi gibi bazı tutarsızlıkları da içermektedir. Mevzuata dayalı olarak sit alanlarının yapılaşma koşulları çerçevesinde değerlendirildiğinde bu alanların büyük bir kısmına planlama ile yerleşilemeyeceği görülmektedir. Foça gibi çok geniş sit alanlarının yanı sıra turizm gibi gelişme potansiyeline sahip bölgelerde koruma ve gelişme süreçleri kaçınılmaz olarak birbirine zıt süreçler olarak işlemekte, bu süreçlerin aktörleri karşı karşıya gelmekte ve sorunlar çözümsüz kalmaktadır. Bu durum, mevcut koruma yaklaşımı ile yukarıdan aşağıya planlama sisteminin gözden geçirilmesi ve bu zorluklar karşısında yeni yaklaşımlar geliştirmesi gerekliliğini ortaya koymaktadır.

\section{Foça'nın Planlama Süreci Üst Ölçekli Planlar}

İzmir Kalkınma Ajansı tarafından 2014-2023 yılları için hazırlanan İzmir Bölge Planı'nda vizyon “Bilgi, Tasarım ve Yenilik Üreten, Akdeniz'in Çekim Merkezi İzmir" olarak belirlenmiştir. Bu vizyona ulaşılırken "Sosyal İçerme, Sürdürülebilirlik, Katılımcılık ve Yenilikçilik" ilkeleri temel alınmıştır. Bu doğrultuda İzmir'in Bölgesel Mekânsal Gelişme Şeması oluşturulurken, Bölgesel Gelişme Odakları belirlenmiştir. Foça ilçesi, Bölgesel Gelişme Odaklarında çevrelerindeki turizm merkezleriyle bağlantılı, doğal, kültürel ve tarihi açıdan çekim noktalarına sahip bir ilçe olarak "İkincil Turizm Odakları" arasında yer almıştır. Bölgesel Mekânsal Gelişim Şemasıyla öncelikle doğal ve arkeolojik sit alanları, içme suyu koruma alanları, çevre koruma alanları, orman, mutlak tarım-özel ürün ve dikili tarım arazileri koruma alanları olarak gruplanmıştır. Bu kapsamda İzmir'de çok geniş ve bütünsel korunması gereken alanlar olduğu görülmüştür. Doğal ve tarihi/arkeolojik değerleriyle Foça ilçesi de bu bütünün içindedir ve sürdürülebilirlik çerçevesinde Mekânsal Gelişim Şemasında "turizm odağı" olarak yer almıştır.

Çevre ve Orman Bakanlığı tarafından yaptırılarak 2007 yılında onaylanan 1/100.000 ölçekli Manisa-Kütahya-İzmir Planlama Bölgesi Çevre Düzeni Planı, İzmir İl sınırları içindeki alanları kapsayan üst ölçekli mekânsal plan niteliğindedir. ${ }^{26}$ Planda kıyılarda yapılaşma baskısının önlenmesi için ana karar verilmiştir:

25 Gültekin, "Kentsel Korumada Temel Kavramlar".

26 T.C. Çevre ve Şehircilik Bakanlığı, İzmir İli Bütünleşik Kıyı Alanları Yönetim ve Planlama Projesi Kıyı Alanları Mekansal Strateji Planı (Ankara: T.C. Çevre ve Şehircilik Bakanlığı, 2012). 
İzmir çevresindeki kıyılarda, gereksinim dışı ikinci konut yapılaşmalarının yarattığı baskılar günümüzde de sürmektedir. Bu baskıların sonuç ürünü olan yanlış yapılaşma örneklerinin büyük bölümünün, mevzi de olsa bir plan kararına da dayandırıldığı bilinmektedir. Bu nedenle, yapılan yeni düzenlemelerde, kıyı kesimlerinde ilave yapılaşmalardan, mevcut yapılaşmalar ile onaylı plan kararlarında yoğunlaşmalara yol açacak düzenlemelerden kaçınılmıştır. ${ }^{27}$

Ancak Çevre Düzeni Planı yargı kararı ile iptal edilmiştir.

İzmir-Manisa Planlama Bölgesi 1/100.000 Ölçekli Çevre Düzeni Planı́nda, Özel Çevre Koruma Bölgesi içinde yer alan ve büyük bölümü arkeolojik ve doğal sit niteliğinde olan Foça'da, mevcut 1/25.000 ölçekli Çevre Düzeni Planı kararları korunmuştur. Plan kararlarında şu ifadelere yer verilmektedir:

Büyük bölümü arkeolojik sit ve doğal sit alanı olan Foça ilçe merkezinde projeksiyonlar sonucu elde edilen nüfus büyüklüğünün yerleştirilmesinde önemli sorunlar yaşanacaktır. Önemli oranda yazlık, ikinci konut gelişiminin gözlendiği ve buna bağlı bir nüfus artışının gözlendiği Foça ilçe merkezi için elde edilen projeksiyon değerinin altında bir değer hedef yıl için nüfus büyüklüğü olarak kabul edilmiştir. Çevresi tarımsal alan olan ve İzmir merkeze yakınlığı nedeniyle gelişme eğilimi gözlenen 5747 sayılı Yasa ile Foça'nın mahallesi durumuna gelen Gerenköy ve Bağarası'nda ikinci konut nitelikli gelişmeleri özendirmeyecek bir nüfus büyüklüğü, projeksiyon sonucuna yakın değerlerde kabul edilmiştir. Foça ilçe sınırları içinde hızlı nüfus artış eğilimi gözlenen bir diğer yerleşme de Yeni Foça yerleşmesidir. Diğer ilk kademe belediyeleri gibi mahalleye dönüşmüş olan Yenifoça'da yapılan hesaplamalar sonucunda ortaya çıkan değer, oldukça hızlı bir artış çizgisini işaret etmektedir. Yerleşme için yapılan projeksiyon sonucu, arttırılmadan kabul edilmiştir. ${ }^{28}$

İzmir İli Bütünleşik Kıyı Alanları Yönetim ve Planlama Projesi Kıyı Alanları Mekansal Strateji Planı kapsamında, Foça ilçesinin kıyıları "doğal niteliklerini koruyan ve yerel sosyo-ekonomik yapısını sürdüren doğa ile uyumlu sürdürülebilir turizmin gelişebileceği bir yöre" olarak tanımlanmıştır. Yönetim ve Planlama Projesi'nde, Foça kenti sit alanlarında yapılaşma ve faaliyetlerin, yerleşmenin özgün kimliğini koruyacak biçimde koruma amaçlı imar planlarına göre sürdürülmesi; kıyı ve deniz ekosisteminin, deniz koruma alanlarının ve deniz canlılarının korunması; Özel Çevre Koruma Alanındaki faaliyetlerin yönetim planına göre sürdürülmesi; kıyılarda doğal kıyı karakterlerinin, kayalık ve mağaraların, orman, makilik ve zeytinliklerin korunması ve kıyıda kaçak yapılaşmanın önlenmesi, çevre ve koruma öncelikleri olarak yer almıştır.

Uluslararası çevre sözleşmeleri gereği Foça ve çevresi Akdeniz foklarının varlığ1 nedeni ile 22.10.1990 tarih ve 90/1117 sayılı Bakanlar Kurulu Kararıla Özel Çevre Koruma Bölgesi olarak ilan edilmiştir. ${ }^{29}$ Tespit ve ilan edilen bölgenin sınırları, 21.5.2007 tarihli ve 2007/12212 sayılı Bakanlar Kurulu Kararı ile genişletilerek yeniden düzenlenmiştir. ${ }^{30}$ Foça Özel Çevre Koruma Bölgesi'nde gerekli korumanın gerçekleştirilebilmesi için, Özel Çevre Koruma Kurumu

27 T.C. Çevre ve Şehircilik Bakanlığı, İzmir İli Bütünleşik Kıyı Alanları Yönetim ve Planlama Projesi Kıyı Alanları Mekansal Strateji Planı.

28 T.C. Çevre ve Şehircilik Bakanlığı, Izmir-Manisa Planlama Bölgesi 1/100.000 Ölçekli Çevre Düzeni Planı Plan Açıklama Raporu (Ankara: T.C. Çevre ve Şehircilik Bakanlığı, 2014).

29 T.C. Çevre ve Şehircilik Bakanlığı, Foça Özel Çevre Koruma Bölgesi Yönetim Planı Raporu.

30 T.C. Çevre ve Şehircilik Bakanlığı, Foça Özel Çevre Koruma Bölgesi Yönetim Planı Raporu. 
Başkanlığı́nca hazırlanan bir Yönetim Planı uygulanmaya başlanmıştır. Yönetim planının amacı şöyle saptanmıştır:

Foça Özel Çevre Koruma Bölgesi'ndeki doğal güzellikleri, tarihi ve kültürel kaynakları, biyolojik çeşitliliği, sualtı, su üstü canlı ve cansız varlıkları korumak ve bu değerlerin gelecek nesillere aktarılarak, sürdürülebilirlik anlayışı çerçevesinde bölgenin ekonomik gelişmesini sağlamak ve çevre bilincini artirmak. $^{31}$

Foça Özel Çevre Koruma Bölgesine ilişkin onaylı 1/25000 ölçekli Çevre Düzeni Planı, söz konusu alanın büyük bir bölümünün Askeri Bölge olması sebebiyle hazırlanmamış, ancak çevre illerle birlikte yapılan 1/100.000 ölçekli çevre düzeni planı paftalarına Foça Özel Çevre Koruma Bölgesi plan kararları

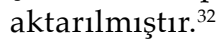

Foça'ya yönelik üst ölçek plan kararları incelendiğinde planlarda Foça için ortak bir çerçevede "koruma" yaklaşımının yanında turizm gelişiminin benimsendiği ve bu yaklaşımın "sürdürülebilirlik" kapsamında geliştirildiği görülmektedir. Ancak yapılan projeksiyon hesaplarında turizm gelişiminin de etkisiyle nüfusun hızla arttığı ve koruma yaklaşımı benimsenen doğal-tarihi/ arkeolojik-kentsel sit alanları nedeniyle ilçenin projeksiyon nüfusu barındırmada yetersiz kalabileceği vurgulanmaktadır.

\section{Foça'nın Nazım İmar Planları}

İzmir ilinin Foça ilçesine ait ve yörenin gelişimini önemli ölçüde yönlendiren ilk nazım planlar 21.4.1981 tarihinde Bayındırlık ve İskân Bakanlığı'nca onaylı 1/25.000 Ölçekli Foça Yenifoça Kıyı Kesimi Nazım İmar Planı ve 14.9.1984 tarihinde Bayındırlık ve İskân Bakanlığı'nca onaylı 1/25.000 Ölçekli Foça Yenifoça Kıyı Kesimi Nazım İmar Planı'dır. ${ }^{33}$

Foça-Yenifoça Kıyı Kesiminde toplam 3.633 hektar alana ait nazım imar planı bulunmaktadır. Söz konusu planlar 1984'den bu yana sit kararlarındaki değişiklikler ve alanın büyük bir kısmının Özel Çevre Koruma Bölgesi ilan edilmesi sonucunda güncelliğini yitirmiş ve uygulanamaz hale gelmiş olup, revize edilme gereği ortaya çıkmasına rağmen söz konusu planlar 1984 yılından bu yana güncellenmemiş ve revize edilmemiştir. ${ }^{34}$

Büyükşehir sınırlarını kapsayan 1/25.000 ölçekli İzmir Kentsel Bölge Nazım İmar Planı, İzmir Büyükşehir Belediyesi tarafından 16.3.2007 tarihinde 315 sayılı karar ile İzmir Büyükşehir Belediye Meclisi tarafından onaylanmıştır. İzmir kentsel bölgeye ilişkin sosyal, ekonomik ve demografik hedefleri gözden geçirmek ve mekânsal düzenlemelere ilişkin karar ve stratejileri yeni veriler doğrultusunda revize etmek amacı ile İzmir Kentsel Bölge Nazım İmar Planı Mayıs 2008'de revize edilmiş ve İzmir Büyükşehir Belediye Meclisi'nce onaylanmıştır. ${ }^{35}$ Planın bütününde koruma anlayışı gözetilmiştir ve bu planda Foça ilçesi, turizm potansiyelleriyle ön plana çıkan ve kıyı turizm aksında yer alan önemli bir noktadadır.

31 T.C. Çevre ve Şehircilik Bakanlığı, Foça Özel Çevre Koruma Bölgesi Yönetim Planı Raporu.

32 T.C. Çevre ve Şehircilik Bakanlığı, Foça Özel Çevre Koruma Bölgesi Yönetim Planı Raporu.

33 İzmir Büyükşehir Belediyesi, 1/25000 Ölçekli İzmir Kentsel Bölge Nazım İmar Planı Revizyonu Açıklama Raporu (İzmir: İzmir Büyükşehir Belediyesi, 2009).

34 İzmir Büyükşehir Belediyesi, 1/25000 Ölçekli İzmir Kentsel Bölge Nazım İmar Planı Revizyonu Açıklama Raporu.

35 T.C. Çevre ve Şehircilik Bakanlığı, İzmir İli Bütünleşik Kıyı Alanları Yönetim ve Planlama Projesi Kıyı Alanları Mekansal Strateji Planı. 
İzmir 1/25.000 ölçekli Kentsel Bölge Nazım İmar Planı için bir revizyon oluşturulmuştur:

Çevre düzeni planlarında var olan sit kararlarının derecelerinde ve sınırlarında onay sonrasında oluşan değişiklikler, çevre düzeni planlarının bazı bölümlerindeki kararları geçersiz kılarken, bazı bölümlerde çevre düzeni planları hatalı uygulamalara neden olabilmektedir. Örneğin, Foça ve çevresindeki çevre düzeni planlarında gösterilen çok sayıda sit alanı sınırlarında ve derecelerinde değişiklikler olmuş, aynı zamanda alanın büyük bir kısmının Özel Çevre Koruma Bölgesi ilan edilmesi de bu bölgedeki planın gözden geçirilmesi sonucunu doğurmuştur. ${ }^{36}$

Plan revizyonunda Foça'nın koruma alanlarına ilişkin şu değerlendirmelere yer verilir:

Bölgede sit alanlarının sınır ve derecelerinde yapılan değişiklikler korunması gerekli doğal ve kültürel alanların bütüncül olarak korunması ilkesini zorlamaktadır.

Foça ve Yenifoça yöresindeki arkeolojik ve doğal sit alanlarının fazla olması kamusal hizmetlerin hızlı bir şekilde yapılmasını yavaşlatmaktadır.

Foça'da sürdürülen arkeolojik kazılar doğrultusunda ortaya çıarılan tarihi eserlerin sergilenebileceği bir arkeoloji müzesi bulunmamaktadır.

Foça İlçesi fokları ve sahip olduğu doğal ve tarihi değerleri ile hızla gelişmekte olan bir turizm potansiyeli taşımaktadır.

Foça İlçe turizminin geliştirilmesi amacıyla, tarihi yapılar ve tescilli konutların aslına uygun olarak restore edilmesi; Karagöl ve Kuş Cenneti'nin ulaşımının kolaylaştırılması; turistlere yönelik dinlenme tesislerinin yapılması ve ilçe halkının turizm açısından bilgilendirilmesi sağlanmalıdır. ${ }^{37}$

Ayrıca Foça'da planlamanın sınırlandırıldı̆̆ı vurgulanmıştır:

Eski Foça-Yeni Foça kıyı bandında, mevcut çevre düzeni planı kararları, doğal ve arkeolojik sit kararları ile orman ve eğimden kaynaklanan doğal eşikler gelişmenin sınırlarını çizmektedir. Ayrıca yerleşim alanlarını kuşatan askeri alanlar önemli sınırlayıcılar arasında bulunmaktadır. Bu eşikler özellikle Foça'da yeni gelişme alanlarının açılmasını engellemektedir. ${ }^{38}$

Plan revizyonunda Kuzey Kentsel Gelişme Alt Bölgesi'nde olan Foça ilçesinin doğal ve tarihi/arkeolojik koruma alanları, turizm ve ikincil konut sektörü ağırlıklı gelişmesi öngörülen Kuzey Turizm Program Alanı olarak yer almıştır. Kuzey Turizm Program Alanı'nın, Foça-Yenifoça kıyı bandında mevcut turizm tesisi ve turizm konut kimliğini sürdürmesi, barındırdığı tarihsel arkeolojik miras ve kıyı kullanım olanakları ile İzmir Kentsel Bölgenin önemli turizm merkezlerinden biri olması öngörülmüştür. Bu program alanında özellikle turizm-ikinci konut ve günübirlik rekreasyon sektörlerinde gelişmesine yönelik kararlar alınmıştır. Program alanında, turizm yatak kapasitesinin artırılması, arkeolojik ören yeri düzenlemeleri, deniz ulaşımı başlıca yatırım sektörleri olacaktır. ${ }^{39}$ Plan kapsamında Foça'nın 2008 yılı nüfusu 28.949, hedef yıl olan 2030

36 İzmir Büyükşehir Belediyesi, 1/25000 Ölçekli İzmir Kentsel Bölge Nazım İmar Planı Revizyonu Açıklama Raporu.

37 İzmir Büyükşehir Belediyesi, 1/25000 Ölçekli İzmir Kentsel Bölge Nazım İmar Planı Revizyonu Açılama Raporu.

38 İzmir Büyükşehir Belediyesi, 1/25000 Ölçekli İzmir Kentsel Bölge Nazım İmar Planı Revizyonu Açılama Raporu.

39 İzmir Büyükşehir Belediyesi, 1/25000 Ölçekli İzmir Kentsel Bölge Nazım İmar Planı Revizyonu Açıklama Raporu. 
yılı toplam plan nüfusu 83.576 kişidir. Bu planda yapılan en önemli değişiklik sınırları yeniden belirlenen Foça Özel Çevre Koruma Bölgesi sınırlarının plana aktarılmasıdır. Her tür ve ölçekte plan yapma, yaptırma ve onama yetkisi Özel Çevre Koruma Kurumu Başkanlığı'na ait olduğundan söz konusu bölge içerisinde plan kararı getirilmemiştir. Yenifoça yerleşmesi mevcut imar planı kararları da göz önüne alınarak ağırlıklı olarak turizm ve tercihli kullanım alanları olarak planlanmıştır. Yenifoça yerleşmesinin çevresi doğal sit alanları olarak tescillenmiştir.

Foça'ya yönelik nazım imar plan kararları incelendiğinde; 1981'de yapılan Foça-Yenifoça Kıyı Kesimi Nazım İmar Planı́nın Foça'ya yönelik en eski plan olduğu ve bu nedenle planlama sürecinde öncü konumunda yer aldığ görülmektedir. 2007'de yapılan ve sonrasında da revizyonu gerçekleştirilen İzmir Kentsel Bölge Nazım İmar Planı'nın ise üst ölçek planlarıyla aynı çerçevede "koruma" yaklaşımının yanında turizm gelişiminin benimsendiği ve bu yaklaşımın "sürdürülebilirlik" kapsamında geliştirildiği belirtilmektedir. Üst ölçek planlarında belirtilen ilçenin projeksiyon nüfusu barındırmada yetersiz kalabileceği düşüncesi; alt ölçek planlarında mevcut çevre düzeni planı kararları, doğal ve arkeolojik sit kararları, orman ve eğimden kaynaklanan doğal eşikler ve yerleşim alanlarını kuşatan askeri alanlar gibi nedenlere bağlanmakta ve planlamanın sınırlandırıldığı vurgulanmaktadır.

\section{Foça Koruma Amaçlı İmar Planı}

Foça'nın Özel Çevre Koruma Bölgesi olarak ilan edildiği tarihten sonra, Foça 1/1000 ölçekli Koruma Amaçlı Revizyon İmar Planı 10.4.1991 tarihinde Özel Çevre Koruma Kurumunca onaylanmıştır. Ancak İzmir II. İdare Mahkemesi'nde 1992/395 Esas Numaralı açlan dava sonucu plan iptal edilmiştir. ${ }^{40}$

Bunun üzerine çalışmalara yeniden başlanmış ve İzmir I Numaralı Kültür ve Tabiat Varlıkları Koruma Kurulu'nun 12.3.1994 tarih ve 4968 sayılı Kurul Kararı gereği planın iki ayrı etap halinde (1. Etap: A-3 alanlarında yoğunluk irdelenerek Kentsel Sit dışı, 2. Etap: Kentsel Sit, Arkeolojik Sit + Kentsel Sit Alanları) Foça Belediyesi, İzmir I Numaralı Kültür ve Tabiat Varlıkları Koruma Kurulu Müdürlüğü ile kurum arasında koordinasyon içerisinde hazırlanması öngörülmüştür. ${ }^{41}$

Foça I. Etap Koruma Amaçlı Revizyon İmar Planı İzmir I Numaralı Kültür ve Tabiat Varlıkları Koruma Kurulu Müdürlüğü'nün 25.12.1997 tarih ve 6982 sayılı Kurul Kararı ile uygun görülmüş ve Özel Çevre Koruma Kurumu Başkanlığı́nca 20.5.1998 tarihinde onaylanmıştır. Söz konusu plan, yasal askı süresinde yapılan itirazlar doğrultusunda yeniden değerlendirilmiş, 1.2.1999 tarihinde Foça I. Etap Koruma Amaçlı İmar Planı değişikliği kesinleşmiştir. İzmir İli, Foça İlçesine ilişkin Kentsel Sit, Kentsel Sit-Arkeolojik Sit ve Kentsel + III. Derece Arkeolojik Sit Alanlarını kapsayan 1/1000 ölçekli Foça 2. Etap Koruma Amaçlı Revizyon İmar Planları ${ }^{42}$ İzmir II Numaralı Kültür Varlıkları Koruma Kurulu Müdürlüğ̈̈'nce onaylanmıştır.

Doğal ve Tarihi/Arkeolojik Değerlere Sahip Foça'nın Koruma, Geliştirme ve Planlama Süreçleri Çerçevesinde Değerlendirilmesi

Foça coğrafi konumu, doğal eşikleri, Gediz Havzası'nda yer alması, geniş ormanları, orman köyleri, askeri bölge olması nedeniyle geniş ve bozulmamış

40 T.C. Çevre ve Şehircilik Bakanlığı, Foça Özel Çevre Koruma Bölgesi Yönetim Planı Raporu.

41 T.C. Çevre ve Şehircilik Bakanlığı, Foça Özel Çevre Koruma Bölgesi Yönetim Planı Raporu.

42 T.C. Çevre ve Şehircilik Bakanlığı, Foça Özel Çevre Koruma Bölgesi Yönetim Planı Raporu. 
doğa parçalarının bulunması, doğal-tarihi/arkeolojik-kültürel değerleriyle turizm potansiyelleri oluşturması, ulusal ve uluslararası ölçekte koruma kararlarının olması, 10 çeşit sit alanının bulunması ve 1981'den bugüne planlı bir gelişim sürecinin olması gibi avantajlara sahiptir. Öte yandan nüfusun hızla artması, Özel Çevre Koruma Bölgesi ilan edilmesiyle balıkçılık gelişiminin azalması, askeri bölgeler ile doğal-tarihi/arkeolojik değerlerin yerleşimi ve planlamayı sınırlandırarak projeksiyon nüfusu barındırmada yetersiz kalabileceği, planlamaya yönelik uygulama ve yönetim sorunlarının olması gibi dezavantajlara da sahiptir.

Tarih bir kentin geçmişidir. Tarihi/arkeolojik değerler de kentin geçmişini günümüze yansıtan en büyük miraslardır. Foça ilçesi, bünyesinde barındırdığ1 bu mirasları koruma kararlarıyla ve planlarla kısmen koruyabilmiştir. Ancak gerek hizla gelişen turizmin etkileri gerek yerel halkın koruma alanında yeterli bilince ulaşamaması, gerekse yönetimle ilgili çatışmalar ve sorunlar, tarihi/ arkeolojik ve doğal değerler ile günümüz yaşantısının bir arada sürdürülmesini olumsuz etkilemektedir. Bir taraftan geliştirme, canlandırma ve koruma hedeflerinin bir arada gerçekleştirilmeye çalışılması bu olumsuzlukların nedeni olarak ortaya çıkmaktadır. ${ }^{43}$ Diğer taraftan korunması gereken canlıların yaşam alanlarının işgal edilmesi, fok mağaralarına turistik dalışlar yapılması, artan nüfusla deniz ve kıyı alanlarındaki kirliliğin artması da doğal alanların korunmasında karşılaşılan zorluklar olarak ortaya çıkmaktadır. Hem tarihi/ arkeolojik hem de doğal değerlerin koruma-kullanma dengesinin yeterince sağlanamaması ve konunun tarafları olan yörede yaşayanlar, yerel ve merkezi yönetimler ile yöreye dışarıdan gelen ziyaretçilerin zaman zaman çatışan taraflar olması, bir planlama sorunu olarak karşımıza çıkmaktadır. Türk planlama sistemi içerisinde üst ölçekten alt ölçeğe çok sayıda farklı plan türü ve bu planlardan sorumlu farklı kurum ve kuruluş da ortaya çıkan sorunların planlama ile çözümünü olanaksız kılmaktadır. Bu süreçte en etkili olabilecek yöntem planlama sürecinin yerelden başlatılması, farkındalığın arttırılması ve sürdürülebilirlik çerçevesinde koruma-kullanma dengesinin sağlanması olacaktır.

\section{Sonuç}

Ekonomi ve teknoloji ile ilgili gelişmeler, dünya toplumları üzerinde bir ağ oluşturarak bu toplumları birbirine bağlamıştır ve birbirlerinden etkilenmelerine yol açmıştır. Öte yandan, bu gelişmeler ortak bazı çevresel sorunları da beraberinde getirdiğinden, çevreyi temel olarak alan yeni bir küreselleşme eğilimi doğmuş; kalkınmanın ve çevre korumanın sürekliliği bir ilgi alanı olarak ortaya çıkmıştır. ${ }^{44}$ Böylelikle, günümüzde küreselleşme sürecinin etkisiyle farklılaşan kentlerde kalkınma ve koruma birlikte değerlendirilmeye başlanmıştır. $\mathrm{Bu}$ değerlendirme sürdürülebilirlik olgusunu da beraberinde getirmiştir. Sürdürülebilirlik kavramının çıkış noktası, ekonomik ve teknolojik gelişmelere paralel bir şekilde ortaya çıkan çevre sorunlarının önüne geçebilme ve ekosistemin korunması üzerine odaklanmıştır. ${ }^{45}$

43 İlhan Tekeli, İzmir-Tarih Projesi Tasarım Stratejisi Raporu (İzmir: İzmir Büyükşehir Belediyesi, 2015).

44 Şafak Kaypak, “Küreselleşme Sürecinde Sürdürülebilir Bir Kalkınma İçin Sürdürülebilir Bir Çevre", KMÜ Sosyal ve Ekonomik Araştırmalar Dergisi 13, no. 20 (2011): 19-33.

45 Elif Karakurt Tosun, “Sürdürülebilirlik Olgusu ve Kentsel Yapıya Etkileri”, Paradoks: Ekonomi, Sosyoloji ve Politika Dergisi 5, no. 2 (2009). 
Kültürel miras değerlerini gerek kültürel süreklilik ve sosyal çeşitliliğin korunması, yaşatılması gerekse ekonomik gelişme ve canlanma sağlanması açısından stratejik mekânsal planlama yaklaşımı temelinde ele alan geniş kapsamlı ve bütünleşik koruma yaklaşımı ${ }^{46}$ olan sürdürülebilirlik, nüfusun giderek daha çok kıyılarda yer seçme eğilimi ve taşınmaz kültür ve tabiat varlıklarına sahip olan yerleşimlerde yaşanan koruma ile gelişme arasındaki mücadeleler için bir araç olarak düşünülebilir. Ancak İlhan Tekeli'nin de ifade ettiği gibi çok karmaşık olan bir sosyo-ekonomik sistem ile çevresinde sürdürülebilirlik koşulunu gerçekleştirebilmenin tek yolu yoktur. ${ }^{47} \mathrm{Bu}$ koşul çok değişik kabullerden yola çıkarak toplumun değişik ögelerine yapılabilecek müdahalelerle gerçekleştirilebilir. Farklı ülkelerde değişik aktörler, değişik ölçeklerdeki birimlere, değişik türde müdahalelerle, sürdürülebilirlik koşulunu gerçekleştirmeye çalışmaktadırlar.

$\mathrm{Bu}$ çerçevede düşünüldüğünde, adını doğal liman yapısındaki adalarında barındırdığı nesli tehlike altındaki fok balıklarından alan ve geçmişten günümüze İyon, Pers, Roma, Bizans, Osmanlı gibi büyük uygarlıklara ev sahipliği yaparak doğal ve tarihi/arkeolojik değerleriyle ön plana çıkan kentsel kıyı yerleşimi Foça, küreselleşmenin etkisiyle gerçekleşen değişim sürecinde sadece klasik kentsel koruma olan "korunan alanlar için klasik ve merkeziyetçi koruma yaklaşımları yerine yeni, daha etkili ve yerelden koruma ve planlama araçlarının gerekliliğini" ${ }^{\prime 48}$ vurgulayan ve sürdürülebilirlik çerçevesinde kent planlama/yönetimi sorunlarını da ele alan çözümler üretmelidir.

Kentlerin değişim süreci, kent yönetiminde zorlukların kaynağı olarak değerlendirildiği için Habitat III Küresel Zirvesi'nin “değişimin kabul edilebilir sınırlarıyla" birlikte ele alınan bütünleştirici arayışları, klasik kentsel koruma paradigmasının dönüşümüne yardımcı olmalıdır. Foça'da bulunan doğal ve tarihi/arkeolojik değerler kentten bağımsız düşünülmemeli, kentsel dinamiklerin akışı içerisinde yer almalıdır. Bütünleştirici yaklaşımlar içerisinde yer alan tarihi/arkeolojik doğal değerlere ilişkin planlama arayışları, Foça'nın sürdürülebilir planlamasını yeniden tanımlanmasını gerektirmektedir. Kentlerin planlama/yönetim sorununun en önemli etkeni olan merkezi yönetimler ile yerel yönetimler arasındaki çatışmayı çözecek yaklaşımlar önem kazanmaktadır. Merkezi yönetimler yerele kendi dinamiklerini tüm paydaşların katılımıyla yönlendirme fırsatı vermelidir. ${ }^{49}$ Yaşanan çevreye yapılacak müdahaleler, yerelde yaşayanlar ya da dışarıdan gelen ziyaretçiler için tarihsel geçmişin izlerini aktarırken, kültürün doğanın sürekliliği bilincini kazandırmalıdır. Planlamanın görevi yaşamı geçmişe referansla donduran değil yeni yaşamın içerisine geçmişin eklemlenmesi ile çevreyi geliştirici ve zenginleştirici çözüm arayışları içerisinde olmalıdır.

46 Koray Özcan, “Sürdürülebilir Kentsel Korumanın Olabilirliği Üzerine Bir Yaklaşım Önerisi: Konya Tarihi Kent Merkezi Örneği”, METU JFA 26, no. 2 (2009): 1-18, https://doi. org/10.4305/METU.JFA.2009.2.1.

47 İlhan Tekeli, “Sürdürülebilir Bir Toplum ve Çevre Tasarımı İçin Bir Strateji Seçenekleri Yelpazesi Oluşturmak", İmir Ekoloji Forumu Hazırlık Çalışmaları ve Sonuç Raporları içinde, der. Ayşe Filibeli, Melek Demir (İzmir: İzmir Akdeniz Akademisi, 2015), 69-130.

48 Gül Güneş, “Korunan Alanların Yönetiminde Yeni Bir Yaklaşım: Katılımcı Yönetim Planlar1", Ekonomi Bilimleri Dergisi 3, no. 1 (2011): 47-57.

49 Rabia Güney ve N. Aydan Sat, “Bölge Planlamada Katılım: İzmir ve Batı Karadeniz Kalkınma Ajansları Üzerine Bir İrdeleme”, Planlama Dergisi 26, no. 2 (2016): 101-116, https://doi. org/10.14744/planlama.2016.25743. 
Sonuç olarak tarihi ve doğal değerlere sahip kentler durağan değildir. Tarihsel derinlik yanında yeni kent, yaşantısına gelişerek devam etmekte ve bu iki kesim bir arada karmaşık bir sistem oluşturmaktadır. Kentsel mirasın yönetimi, bu farklılaşma konusunda ve kentlerin küresel dünyadaki yeni rolü, sürdürülebilirlik, turizm baskısı, iklim değişimi, sürekli bir dönüşüm içerisinde olan kültürel miras, çağdaş mimarinin gelişimi çerçevelerini de içeren bir farkındalığı gerektirmektedir. Foça örneğinden de anlaşılacağı üzere Türkiye'de iç içe geçmiş farklı ölçeklerde ve çok sayıda farklı türde planlama mekanizmaları ve yanı sıra koruma amaçlı araçlar eş zamanlı çalışmaktadır. Bu kadar fazla plan türü ve kurumsal yapının verimli işleyiş̧i mümkün olmamaktadır. Yerleşim sistemlerinin hızlı değişimi de göz önünde bulundurulduğunda, uluslararası kuruluşların da üzerinde durduğu "kabul edilebilir değişimin sınırları" gibi temel ilkeler üzerinden daha esnek planlama süreçlerinin ve modellerinin geliştirilmesi, örneğin sit alanlarının da planlama sistemi içinde "eylem alanları" ${ }^{50}$ olarak değerlendirilebilmesi gibi toplumun tüm kesimleri için elverişli müdahalelerin yolunu açacaktır. İnsan ve doğa sistemleri insanların doğal bileşenlerle etkileşim içerisinde olduğu bütünleşik ve karmaşık sistemlerdir. Ancak ekolojik ve sosyal bilimler arasındaki geleneksel ayrım bu etkileşimlerin gelişimine engel olmuştur. ${ }^{51}$ Son dönemde ortaya çıkan "karmaşık uyarlanan sistemler" yaklaşımı önümüzdeki dönemde planlama disiplini çerçevesinde önemli açılımlar sağlayacaktır.

\section{Kaynakça}

Arıkan, Zeki. "Henri Pirenne ve Fernand Braudel'e Göre Akdeniz". Akdeniz Tarihi, Kültürü ve Siyaseti "Çoğulluğu ve Farklılı̆̆ İçeren Bir Birlik Özlemi" Sempozyum Bildirileri içinde, derleyenler Alp Yücel Kaya, Ayşegül Sabuktay, Dilek Akyalçın Kaya, Ertekin Akpınar, 39-48. İzmir: İzmir Akdeniz Akademisi, 2016.

Ergürhan, Erhan. “Foça'da Kıyı Alanı Kullanımı ve Kıyı Kullanımı Bilincinin Değerlendirilmesi". Yüksek Lisans Tezi, Dokuz Eylül Üniversitesi, 2008.

Gültekin, Nevin. "Kentsel Korumada Temel Kavramlar", Kentsel Koruma Ders Notlar içinde, 3-4 (2015).

Güneş, Gül. "Korunan Alanların Yönetiminde Yeni Bir Yaklaşım: Katılımcı Yönetim Planları". Ekonomi Bilimleri Dergisi 3, no. 1 (2011): 47-57.

Güney, Rabia ve N. Aydan Sat. “Bölge Planlamada Katılım: İzmir ve Batı Karadeniz Kalkınma Ajansları Üzerine Bir İrdeleme". Planlama Dergisi 26, no. 2 (2016): 101-116. https://doi.org/10.14744/planlama.2016.25743.

Hoşsucu, Hikmet, Adnan Tokaç, Tuncay Kınacıgil, Zafer Tosunoğlu, Okan Akyol, Uğur Özekinci ve Vahdet Ünal. “Balıkçılık Sektörünün İzmir İli İçindeki İşleyişi ve Güncel Sorunları". E.Ü. Su Ürünleri Dergisi 18, no. 3-4 (2001): 437-444.

İZKA ve Dokuz Eylül Üniversitesi Mimarlık Fakültesi. İzmir 2012 Kültür Ekonomisi ve Kültür Altyapısı Envanteri ve İzmir Kültür Ekonomisi Gelişme Stratejisi. İzmir: İZKA, 2013.

İZKA. “2014-2023 İzmir Bölge Planı İlçe Toplantıları Foça İlçe Raporu, Mayıs 2013”. Erişim tarihi 7 Kasım 2016. http://www.izmiriplanliyorum.org/static/upload/file/20142023_ilce_ozet_raporu_-_foca.pdf.

50 Elif Özden Örnek, Zekai Görgülü, “Planlama-Koruma İlişkisi Üzerine Yeni Bir Sistem Önerisi", Megaron: YTÜ Mim. Fak. e-Dergisi 1, no. 4 (2006): 234-255.

51 Jianguo Liu vd., "Complexity of Coupled Human and Natural Systems”, Science 317, no. 5844 (2007): 1513-1516, https://doi.org/10.1126/science.1144004. 
İzmir Büyükşehir Belediyesi. 1/25000 Ölçekli İmir Kentsel Bölge Nazım İmar Planı Revizyonu Açıklama Raporu. İzmir: İzmir Büyükşehir Belediyesi, 2009.

Kaypak, Şafak. "Küreselleşme Sürecinde Sürdürülebilir Bir Kalkınma İçin Sürdürülebilir Bir Çevre". KMÜ Sosyal ve Ekonomik Araştırmalar Dergisi 13, no. 20 (2011): 19-33.

Kıraç, Cem Orkun ve Harun Güçlüsoy. Foça ve Akdeniz Foku: Foça Özel Çevre Koruma Bölgesi'nde Akdeniz Fokunun (Monachus monachus) Korunması ve İzlenmesi. Ankara: T.C. Çevre ve Orman Bakanlığı Özel Çevre Koruma Kurumu Başkanlığı Yayınları, 2008.

Liu, Jianguo, Thomas Dietz, Stephen R. Carpenter, Marina Alberti, Carl Folke, Emilio Moran, Alice N. Pell, vd. "Complexity of Coupled Human and Natural Systems". Science 317, no. 5844 (2007): 1513-1516. https://doi.org/10.1126/science.1144004.

Örnek, Elif Özden ve Zekai Görgülü. "Planlama-Koruma İlişkisi Üzerine Yeni Bir Sistem Önerisi". Megaron: YTÜ Mim. Fak. e-Dergisi 1, no. 4 (2006): 234-255.

Özcan, Koray. "Sürdürülebilir Kentsel Korumanın Olabilirliği Üzerine Bir Yaklaşım Önerisi: Konya Tarihi Kent Merkezi Örneği". METU JFA 26, no. 2 (2009): 1-18. https:// doi.org/10.4305/METU.JFA.2009.2.1.

Özyiğit, Ömer. "Phokaia'da Akurgalı́ı Kazıları Işı̆̆ında Son Dönem Çalışmaları”. Anadolu / Anatolia 25 (2003): 97-107.

Özyiğit, Ömer. "Recent Discoveries At Phocaea”. Empúries 56 (2009-2011): 25-40.

Özüpekçe, Salman. "Turizm Yerleşmelerinde Nüfusun Sosyo-Ekonomik Özelliklerinde Ortaya Çıkan Değişimler ve Eğitim Üzerindeki Etkisi (Foça Örneği)". Yüksek Lisans Tezi, Dokuz Eylül Üniversitesi, 2008.

Santander, Arturo Azpeitia ve Agustín Azkarate Garai-Olaun. "Urban Planning and Sustainable Development in the 21st Century, Conceptual and Management Issues". IOP Conference Series: Earth and Environmental Science 44, no. 3 (2016): 032005. https:// doi.org/10.1088/1755-1315/44/3/032005.

T.C. Çevre ve Şehircilik Bakanlığı. Foça Özel Çevre Koruma Bölgesi Yönetim Planı Raporu. Ankara: T.C. Çevre ve Şehircilik Bakanlığı Tabiat Varlıklarını Koruma Genel Müdürlüğü, 2011.

T.C. Çevre ve Şehircilik Bakanlığı. İzmir İli Bütünleşik Kıyı Alanları Yönetim ve Planlama Projesi Kıyı Alanları Mekansal Strateji Planı. Ankara: T.C. Çevre ve Şehircilik Bakanlığı, 2012.

T.C. Çevre ve Şehircilik Bakanlığı. İzmir-Manisa Planlama Bölgesi 1/100.000 Ölçekli Çevre Düzeni Planı Plan Açıklama Raporu. Ankara: T.C. Çevre ve Şehircilik Bakanlığı, 2014.

Tekeli, İlhan, "Sürdürülebilir Bir Toplum ve Çevre Tasarımı İçin Bir Strateji Seçenekleri Yelpazesi Oluşturmak". İzmir Ekoloji Forumu Hazırlık Çalışmaları ve Sonuç Raporları içinde, derleyenler Ayşe Filibeli, Melek Demir, 69-130. İzmir: İzmir Akdeniz Akademisi, 2015.

Tekeli, İlhan. İzmir-Tarih Projesi Tasarm Stratejisi Raporu. İzmir: İzmir Büyükşehir Belediyesi, 2015.

Tosun, Elif Karakurt. "Sürdürülebilirlik Olgusu ve Kentsel Yapıya Etkileri". Paradoks: Ekonomi, Sosyoloji ve Politika Dergisi 5, no. 2 (2009). 